\title{
Therapeutic Potential of Human Umbilical Cord Blood Derived Mesenchymal Stem Cells in Murine Model of Hepatic Schistosomiasis
}

Mohammad Abd-El Rehiem Bebars ${ }^{1}$, Hanan Hussein Kamel ${ }^{1}$, Hala Gabr ${ }^{2}$, Heba Abdel Kader Aminou ${ }^{1}$, Lobna Sadek Shash ${ }^{3}$, Shaimaa Essam Al-din Mohammed ${ }^{1}$, Ayman Mohammad Abd El Azim Al-Ashkar ${ }^{1,4}$

${ }^{1}$ Department of Medical Parasitology, Faculty of Medicine, Ain Shams University, Cairo, Egypt.

${ }^{2}$ Department of Clinical Pathology, Faculty of Medicine, Cairo University, Cairo, Egypt.

${ }^{3}$ Department of Pathology, Faculty of Medicine, Ain Shams University, Cairo, Egypt.

${ }^{4}$ College of Medicine, University of Bisha, KSA

Corresponding Author Ayman Mohammad Abd El Azim Al-Ashkar

\section{Mobile:}

$+201030876995 /$

$+966502341013$

\section{E mail: \\ aymanpara@yahoo. com}

Key words: Cord blood-derived MSCs; Schistosomiasis mansoni; Liver fibrosis
Background and Aim: The pathogenesis of schistosomiasis is mainly due to the host's immune response against Schistosoma eggs trapped in tissues causing a granulomatous reaction. Recently, stem cell therapy has drawn much attention due to their potential for self-renewal and differentiation. The present study was designed to investigate the regenerative and antifibrotic potential of Human Umbilical Cord Blood derived Mesenchymal Stem Cells (HUCB-MSCs) in hepatic granuloma due to experimental murine model.

Material and Methods: Swiss Albino mice $(n=70)$ were divided into 3 groups; Group A: 30 mice infected with $\mathrm{S}$. mansoni cercariae and subjected to intrahepatic injection of HUCB-MSCs by a single dose of 1 million HUCB-MSCs at 12 weeks post infection (wpi), G (A1): 10 schistosomiasis mansoni in the

mice sacrificed at 16 (wpi), G (A2):10 mice sacrificed at 18 (wpi), G (A3): 10 mice sacrificed at 20 (wpi). Group B: 30 mice infected with $\mathrm{S}$. mansoni cercariae (positive control), G (B1):10 mice sacrificed at 16 (wpi), G (B2):10 mice sacrificed at 18 (wpi), G (B3):10 mice sacrificed at 20 (wpi). Group C: 10 uninfected mice (negative control).

Results: Treatment with HUCB-MSCs, showed an improvement in the histopathological picture of the liver with diminution in the size of granulomas and the overall fibrotic content. Hyperplasic changes in intrahepatic biliary radicals obviously decreased in test groups.

Conclusion: The human umbilical cord blood-derived MSCs are promising and effective therapy for the treatment of diseased or damaged liver tissues.

\section{INTRODUCTION}

Schistosomiasis is an endemic trematode infection in seventy six countries, the majority of which are in Africa. The infected people are nearly 207 million with symptomatic 120 million and severe illness in 20 million [1]. In Egypt, the incidence of this illness is still high despite the great effort to eradicate the disease; sixty percent of the Egyptian population is at risk of infection. School children who live in rural areas are particularly vulnerable to infection [2].

Schistosomiasis mansoni is associated with many complications; the most important of these are liver damage

Bebars et al., Afro-Egypt J Infect Endem Dis 2020;10(2):151-162

https://aeji.journals.ekb.eg/

http://mis.zu.edu.eg/ajied/home.aspx
[3]. The patient's immune system accounts for pathogenesis of schistosomiasis due to trapped Schistosoma eggs in tissues causing a clinical disease. Late granuloma resulted in chronic liver fibrosis with excessive collagen and fibrous tissue deposition [4].

Liver fibrosis has a poor prognosis as it is accompanied by many complications as bleeding oesophageal varices, accumulation of fluid in the peritoneal cavity and encephalopathy as a result of liver cell failure. Although many hopes rely upon liver transplantation as a good treatment, there are few accessible granulomatous reaction that result in 
donors for the hundred millions patients all over the world. So, doctors and scientists should urgently find new treatments [5].

Stem cells are one of the most interesting topics for researchers nowadays. At some point in the future, stem cells will be the basis for what is known as cell-based therapy, relying on replacing diseased or dysfunctioning cells with healthy functioning ones [6].

Researchers mainly study embryonic or adult stem cells of humans and animals. However, usage of human embryonic stem cells, in researches as well as in therapeutics, is limited by ethical consideration [7].

Adult stem cells are present in many tissues as muscle, liver, GIT and bone marrow. Two types of stem cells are present in the adult bone marrow, which are the hematopoietic stem cells (HSCs) and the mesenchymal stem cells (MSCs). The HSCs give rise to all circulating blood cells, while MSCs can be influenced to form different mesenchymal lineages as osteoblastic, chondroblastic and adipocytic lineages when cultured into appropriate environments [8].

MSCs are an attractive therapeutic tool for regenerative medicine, tissue engineering, and different regimes depending on cell treatments due to their easy isolation and culture, highly expansive potential, ability to change into different cells and immunosuppressant properties, [9].

There are many obstacles regarding the usage of BMSCs like aging of these cells and the potential harm that may be resulted from the extraction steps. Ethical conflicts influence many researchers to find different sources of MSCs to overcome that problem. The human umbilical cord blood derived mesenchymal stem cells (HUCMSCs) is considered a source of MSCs that are able of self-renewal, give rise to different cell types, more primitive stem cells, more simply to be obtained, without ethical conflicts and minimally express MHC class II antigens suggesting that they are a preferable cell source for transplantation, without the need of immunosuppressant drugs [10].

The first HUCMSCs transplantation was performed in 1988 followed by many thousands of transplantations until now [11].

This study aims to investigate the restorative and antifibrotic properties of HUCBMSCs in hepatic granuloma due to schistosomiasis mansoni in the experimental murine model.

\section{MATERIAL AND METHODS}

\section{Experimental animals:}

\subsection{Handling and infection:}

7 -week old Swiss Albino mice weighing about 25 grams were kept under the suitable conditions at the Schistosome Biological Material Supply Center of Theodor Bilharz Research Institute (TBRI), Giza, Egypt. Experimental animals were handled according to the NIH guidelines.

Mice infection was done by a single injection of ninety $S$. mansoni cercariae subcutaneously. To be sure of occurrence of infection, stool examination was done finding $S$. mansoni eggs in the stool 42 days post-infection. Five mice were sacrificed 12 wpi to ensure the presence of granuloma.

\subsection{Grouping:}

Test and control groups are classified into 3 groups:

- Group A: 30 infected mice with S. mansoni and exposed to intrahepatic injection of HUCBMSCs at 12 (wpi); $\mathbf{G}$ (A1): 10 mice sacrificed at 16 (wpi), $\mathbf{G}$ (A2): 10 mice sacrificed at 18 (wpi), G (A3): 10 mice sacrificed at 20 (wpi).

- Group B: 30 mice infected with S. mansoni cercariae (positive control); G (B1):10 mice sacrificed at 16 (wpi); G (B2):10 mice scarificed at 18 (wpi); $\mathbf{G}$ (B3): 10 mice sacrificed at 20 (wpi).

- Group C: 10 uninfected mice (negative control).

2. Isolation and harvest of (HUCB-MSCs): [12]

\subsection{Isolation of Human MSCs from Umbilical cord blood:}

Institutional Review Board (IRB) approval and signature of an informed consent was required 
before usage of umbilical cord tissue from human subjects.

- Venipuncture of the umbilical vein was performed by a sterile syringe containing $1 \mathrm{ml}$ of heparin as anti-coagulant.

- Dilution of samples (1:1) with diluted phosphate buffer saline (DPBS) was done then layered over Ficol-Hypaque solution and centrifugation for quarter of an hour at 1200 rpm.

- Mononuclear layer was collected, washed with PBS and centrifugation for 10 minutes at $1200 \mathrm{rpm}$ was performed. Collection of the buffy coat into a clean $15 \mathrm{ml}$ conical tube was done.

- Re-suspension of the cell pellet in $1 \mathrm{ml}$ of culture medium then counting by hemocytometer.

- The viability test was done using trypan blue.

\subsection{Culturing and incubation of $\mathrm{HUCB}$ - MSCs:}

- When $80-90 \%$ confluence was reached, the cells were passaged.

- Aspiration of the medium (Low-glucose Dulbecco's modified Eagle's medium) was done then the cells were rinsed with sterile PBS ( $\mathrm{Ca}++$ free $)$.

- The culture surface was covered by $2 \mathrm{ml}$ warmed, CO2-equilibrated trypsin-EDTA $(0.05 \%)$ then left at room temperature for 5 $\min$.

- An inverted microscope was used to observe the separated cells.

- The trypsinization reaction was neutralized by adding 2-3 times volumes of medium or fetal bovine serum.

- A $15 \mathrm{ml}$ sterile centrifuge tube was used to transfer the media containing the cells and then centrifuged at $1000 \mathrm{rpm}$ for $5 \mathrm{~min}$ at room temperature.

- The cells were re-suspended in fresh medium after discarding the supernatant.

- Counting of cells was done then the cells were transported to a new container with a concentration of 10,000 cells per square $\mathrm{cm}$ in fresh medium and cultured as mentioned previously.

\subsection{Cell and Viability Count:}

- The viability of the cells was checked using $0.4 \%$ Trypan blue.

- Blue was the color of non-viable cells but living cells were unstained.

- Blue and clear cells were counted.

viability $(\%)=$

total viable cells(unstained)

total cells(stained and unstained) $\times 100$

\subsection{Flow cytometry:}

- As in the passage step, the cells were lifted and re-suspended in PBS.

- $100 \mathrm{ul}$ cell suspension were added to conjugated antibody or isotope control and left at room temperature in the dark for 15-20 min.

- After that, washing of the cells was done followed by centrifugation at $1000 \mathrm{rpm}$ for 3 $\min$.

- Aspiration of the supernatant was done then the cells were re-suspended in PBS and ran through the flow cytometer.

- Using Cell Quest software enabled us to collect 10,000 events for each tube.

\begin{tabular}{|l|c|}
\hline \multicolumn{1}{|c|}{ Antibody } & $\begin{array}{c}\text { Antibody per 100 ul } \\
\text { cell suspension }\end{array}$ \\
\hline PE isotype control (IgG1) & $10 \mathrm{ul}$ \\
\hline FITC isotype control (IgG2b) & $10 \mathrm{ul}$ \\
\hline PE CD34(IgG1) & $10 \mathrm{ul}$ \\
\hline PE CD271(IgG2b) & $10 \mathrm{ul}$ \\
\hline PE CD90(IgG1) & $5 \mathrm{ul}$ \\
\hline PE CD105(IgG1) & $3 \mathrm{ul}$ \\
\hline
\end{tabular}

PE:phycoerythrin FITC:fluoreceinisocyanate

\section{Histopathological and Immunohisto- chemical study:}

Paraffin blocks were prepared from $10 \%$ buffered formalin fixed livers extracted from mice. Sections thickness was $4 \mu \mathrm{m}$. $250 \mu \mathrm{m}$ was enough to cut away from the preceding sections by to avoid having specimens from the same granuloma. Haematoxylin and eosin (H\&E), Masson trichrome stains (MT) were used to stain 5 paraffin liver sections from each animal. Additional sequential cuts $(4 \mu \mathrm{m}$ thick $)$ were prepared for immunohistochemical study using mouse monoclonal anti alpha smooth muscle actin antibody (SMA) (DAKO, clone 1A4) diluted 1: 50 (BioGenex, USA). 
Evaluation methodology: Liver sections of (H\&E), (MT) and (SMA) immunohistochemically stained slides were microscopically examined, where 40 granulomas, hepatic histopathological changes and fibrosis were evaluated for every mouse (tab. 1).

Table 1: Histopathological and SMA immunohistochemical evaluation methodology:

\begin{tabular}{|c|c|}
\hline \multicolumn{2}{|r|}{ Assessment of granuloma } \\
\hline \multicolumn{2}{|c|}{$\begin{array}{l}\text { Quantitative assessment of granulomas size was } \\
\text { assessed for the average of } 10 \operatorname{HPF}(\mathrm{x} 400) / \text { mouse } \\
\text { sections } \\
\text { Size was scored as: Score } 1:<250 \mu, \text { Score } 2: 250500 \mu \text {, } \\
\text { Score 3: }>500 \mu^{*}\end{array}$} \\
\hline \multicolumn{2}{|r|}{ Assessment of the extent fibrosis** [13] } \\
\hline \multicolumn{2}{|c|}{$\begin{array}{l}\text { Semi quantitative assessment of peri-glomerular } \\
\text { fibrosis using H\&E and MT stain as: }\end{array}$} \\
\hline Mild & \\
\hline Moderate & $\begin{array}{l}\mathrm{e} \\
\mathrm{g}\end{array}$ \\
\hline Severe & ntral \\
\hline \multicolumn{2}{|c|}{ Assessment extent of associated biliary hyperplasia } \\
\hline \multicolumn{2}{|c|}{$\begin{array}{l}\text { Semi quantitative assessment of reactive hyperplasic } \\
\text { changes in BD within PT as: }\end{array}$} \\
\hline Absent & \\
\hline Gild & of \\
\hline Ioderate & $25-5$ \\
\hline Severe & \\
\hline \multicolumn{2}{|c|}{$\begin{array}{c}\text { Percentage of hepatic stellate cells SMA } \\
\text { expression (in granuloma region/ portal/ peri- } \\
\text { portal region) } * * *[14]\end{array}$} \\
\hline \multicolumn{2}{|c|}{$\begin{array}{l}\text { Semi-quantitative assessment of SMA cytoplasmic } \\
\text { positive of cells within the granuloma, portal and } \\
\text { periportal areas at } 200 \times \text { magnification counted in at } \\
\text { least } 7-10 \text { microscopic fields were determined as: }\end{array}$} \\
\hline core (1) & \\
\hline Score (2) & pos \\
\hline Score (3) & Positive for $>66 \%$ of the region. \\
\hline \multicolumn{2}{|c|}{$\begin{array}{l}\text { HPF: high power field- H\&E: } \\
\text { MT: Masson trichrome stain } \\
\text { BD: bile duct- PT: portal tract-S } \\
\text { actin }\end{array}$} \\
\hline
\end{tabular}

\section{Liver function parameters:}

Serum albumin concentration was determined [15], as well as aminotransferase enzymes; serum glutamic-oxaloacetic transaminase (SGOT) and Serum glutamic pyruvic transaminase (SGPT) activities [16].

\section{Analysis of the results:}

Analysis was done using Statistical package for Social Science (SPSS 15.0.1 for windows; SPSS Inc, Chicago, IL). Student $\mathbf{T}$ test was performed to evaluate the statistical significance of the difference between the means of the study groups.

\section{RESULTS}

\section{Stem cells culture results:}

Sample was isolated in DMEM culture medium. All isolated MSC populations displayed a spindle-shaped morphology.

The cells isolated by gradient density centrifugation showed heterogeneity during the first three days (figs. 1, 2). The adherent spindleshape cells were noticed at day 2 at the bottom of culture flasks (fig. 2). Numerous round cells were floating in the medium. The floating cells decreased after continuous change of medium. The floating cells were absolutely declared from the medium after 2 times of changing the medium. The adhered cells became fibroblastlike (fig. 3). Confluence of the cells occurred 2 weeks after isolation (fig. 4), the subculture of the cells was done using a ratio of 1:3. By this method, we isolated UCB-derived MSCs. In spite of the main shape of passaged cells was spindle-shaped cells, the shape of the cells differ from very thin and elongated to more cuboidal cells with smaller cytoplasmic extensions. 


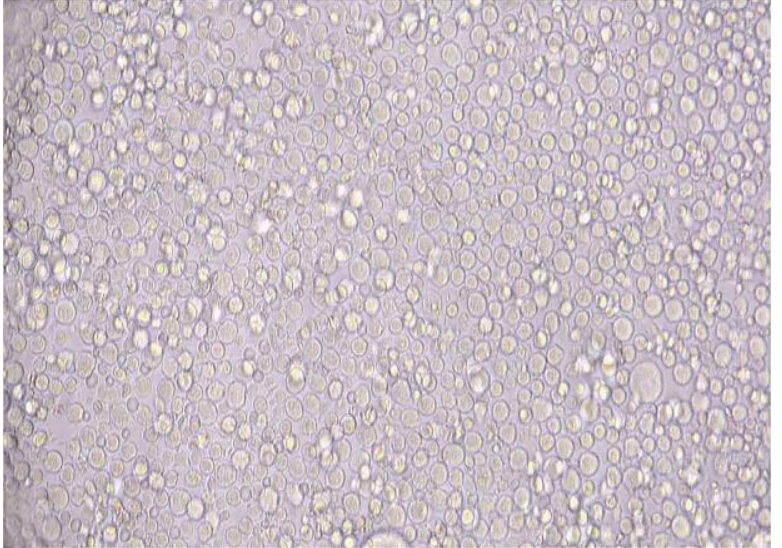

Fig. (1): Morphology of cells after 6 hours resuspended in medium (magnified at 200X)

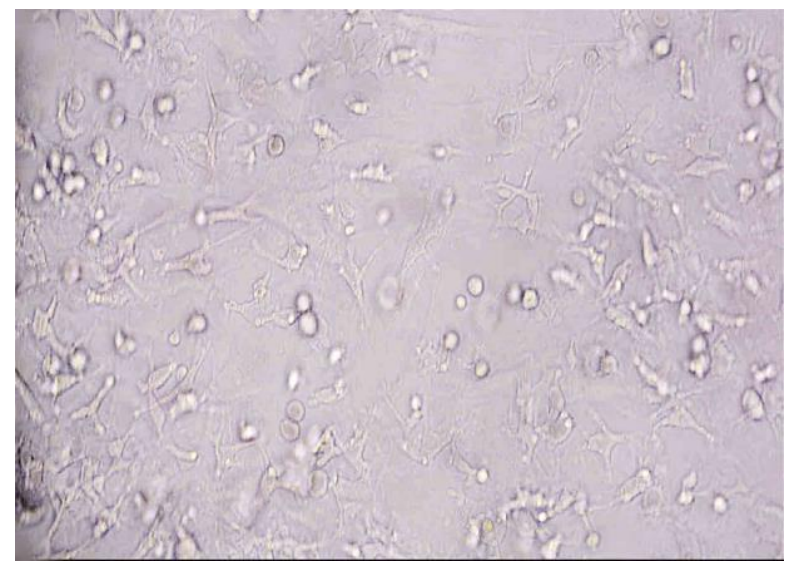

Fig. (3): On days 7, the cells took on the appearance of long spindle-shaped fibroblastic cells, began to form colonies (magnified at 200X).

\section{Immunophenotyping of MSC:}

Surface markers were tested by flowcytometric analysis. All types of MSC and fibroblasts were negative for CD34 and CD45, while they were positive for CD90, CD105, and CD271.

Mesenchymal stem cells with positive CD90, CD271 and very bright (out of scale) CD73 with negative CD34. All this plots are gated on CD45 negative cells.

\section{Histopathological and Immunohisto- chemical results:}

All histopathological and immunohistochemical results are summarized in table 2 . Reduction of

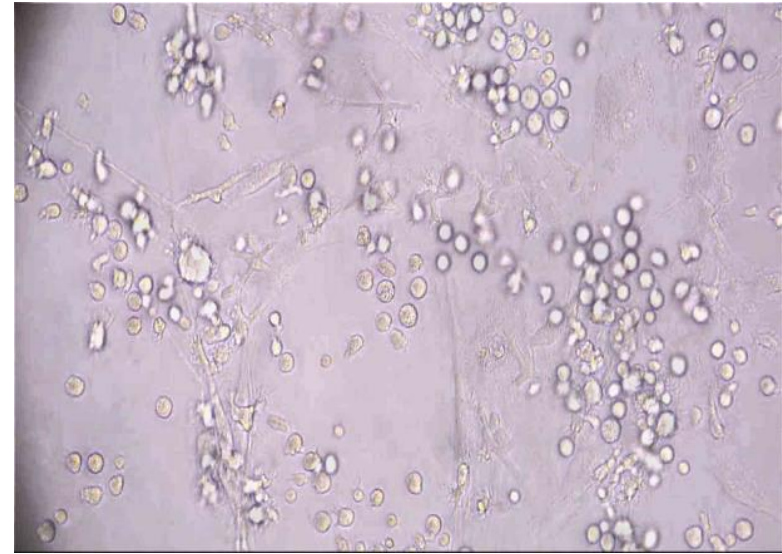

Fig. (2): Primary culture of CB-MSCs on day two of isolation showing adherent cells (magnified at 200X).

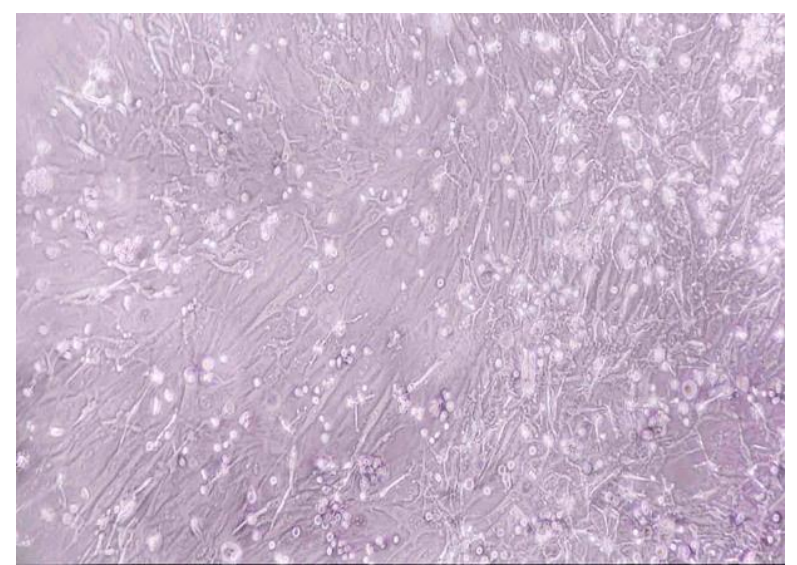

Fig. (4): Cells grew in colonies, reaching confluence after 14 days (magnified at 200X).

the overall pathologic consequences of bilharzial hepatic involvement was remarkable in test groups as compared to control groups; such observation was even more pronounced with increase post injection interval.

Statistically significant differences were reported in granuloma size among control and test groups, moreover, differences in granuloma sizes also showed statistically significant difference between first sacrificed mice test group and latest sacrificed mice group indicating extended action of injected mesenchymal stem cells (figure 5A). 
Table( 2): Histopathological and smooth muscle actin immunohistochemical results.

\begin{tabular}{|c|c|c|c|c|c|c|c|c|c|c|c|}
\hline \multicolumn{12}{|c|}{ Variations of granuloma size in study groups } \\
\hline & \multirow{2}{*}{ Group } & \multirow{2}{*}{\multicolumn{2}{|c|}{$\begin{array}{l}<250 \mu \\
\text { No. }(\%)\end{array}$}} & \multirow{2}{*}{\multicolumn{3}{|c|}{$\begin{array}{l}250-500 \mu \text { No. } \\
(\%)\end{array}$}} & \multirow{2}{*}{\multicolumn{2}{|c|}{$>500 \mu$ No. $(\%)$}} & \multirow[t]{2}{*}{ Total } & \multicolumn{2}{|c|}{ Chi-square } \\
\hline & & & & & & & & & & & p-value \\
\hline \multirow{2}{*}{$16 \mathrm{w}$} & Test (A1) & \multicolumn{2}{|l|}{$3(30 \%)$} & \multicolumn{3}{|c|}{$5(50 \%)$} & \multicolumn{2}{|c|}{$2(20 \%)$} & 10 & \multirow{2}{*}{1.667} & \multirow[t]{2}{*}{0.435} \\
\hline & Control(B1) & \multicolumn{2}{|l|}{$1(10 \%)$} & \multicolumn{3}{|c|}{$5(50 \%)$} & \multicolumn{2}{|c|}{$4(40 \%)$} & 10 & & \\
\hline \multirow[t]{2}{*}{$18 \mathrm{w}$} & Test (A2) & \multicolumn{2}{|l|}{$8(80 \%)$} & \multicolumn{3}{|c|}{$1(10 \%)$} & \multicolumn{2}{|c|}{$1(10 \%)$} & 10 & \multirow[t]{2}{*}{10.889} & \multirow[t]{2}{*}{$0.004 *$} \\
\hline & Control(B2) & \multicolumn{2}{|l|}{$1(10 \%)$} & \multicolumn{3}{|c|}{$1(10 \%)$} & \multicolumn{2}{|c|}{$8(80 \%)$} & 10 & & \\
\hline $20 \mathrm{w}$ & Test(A3) & $9(90 \%)$ & & $1(1$ & & & $0(0 \%$ & & 10 & 16.800 & $<0.001 * *$ \\
\hline & Control (B3) & $0(0 \%)$ & & $4(4$ & & & $6(60$ & & 10 & & \\
\hline & & Histopa & thological & asses & lent & of ext & of fib & osis by $\mathrm{H} \& \mathrm{E}$ & and MT & & \\
\hline & & Abcent & Mild & Mor & & Grat & & & & Chi-squar & \\
\hline Group & & $\begin{array}{l}\text { Absent } \\
\text { No.(\%) }\end{array}$ & $\begin{array}{l}\text { Mild } \\
\text { No. \%) }\end{array}$ & $\begin{array}{l}\text { Moo } \\
\text { No }\end{array}$ & & $\begin{array}{l}\text { Gra } \\
\text { fusi } \\
\text { No. }\end{array}$ & mas & $\begin{array}{l}\mathrm{p}-\mathrm{p} / \mathrm{p}-\mathrm{c} \\
\text { bridging } \\
\text { No. }(\%)\end{array}$ & Total & $\mathrm{X} 2$ & $\mathrm{p}$-value \\
\hline & Test (A1) & $0(0 \%)$ & $4(40 \%)$ & $5(50$ & & $1(10$ & & $0(0 \%)$ & 10 & 1.091 & \\
\hline $16 \mathrm{w}$ & Control (B1) & $0(0 \%)$ & $2(20 \%)$ & $6(60$ & & $2(20$ & & $0(0 \%)$ & 10 & & 0.580 \\
\hline 18 & Test (A2) & $0(0 \%)$ & $7(70 \%)$ & $3(3$ & & $0\left(0^{c}\right.$ & & $0(0 \%)$ & 10 & 13.143 & $0004 *$ \\
\hline $18 \mathrm{w}$ & Control (B2) & $0(0 \%)$ & $0(0 \%)$ & $4(40$ & & $5(50$ & & $1(10 \%)$ & 10 & & $0.004 \%$ \\
\hline 20 & Test (A3) & $2(20 \%)$ & $7(70 \%)$ & $1(10$ & & $0\left(0^{c}\right.$ & & $0(0 \%)$ & 10 & 18.000 & O $001 * *$ \\
\hline $20 \mathrm{~W}$ & Control (B3) & $0(0 \%)$ & $0(0 \%)$ & $1(10$ & & $6(60$ & & $3(30 \%)$ & 10 & & > \\
\hline & & Hist & opatholo & ic as: & sn & t of 1 & erpla & ic biliary che & nges & & \\
\hline & & Absent & $<25 \%$ & f PT & & $50 \%$ & & $>50 \%$ of PT & Total & Chi-squa & \\
\hline & Group & No. $(\%)$ & No. $(9$ & & & $(\%)$ & & No. $(\%)$ & & $\mathrm{X} 2$ & p-value \\
\hline $16 \mathrm{w}$ & Test (A1) & $1(10 \%)$ & $4\left(40^{\circ}\right.$ & & & $0 \%)$ & & $0(0 \%)$ & 10 & 3.111 & 0.375 \\
\hline & Control(B1) & $0(0 \%)$ & $4(40 \%$ & & & $0 \%)$ & & $2(20 \%)$ & 10 & & \\
\hline $18 \mathrm{w}$ & Test (A2) & $2(20 \%)$ & $8(809$ & & & $\%)$ & & $0(0 \%)$ & 10 & 16.444 & $<0.001 * *$ \\
\hline & Control(B2) & $0(0 \%)$ & $1(10 \%$ & & & $0 \%)$ & & $5(50 \%)$ & 10 & & \\
\hline 20 & Test(A3) & $5(50 \%)$ & $5(509$ & & & $\%)$ & & $0(0 \%)$ & 10 & 20.000 & $<0.001 * *$ \\
\hline $\mathrm{w}$ & Control (B3) & $0(0 \%)$ & $0(0 \%)$ & & & $0 \%)$ & & $4(40 \%)$ & 10 & & \\
\hline & & entage of & SMA exp & essio & In $\mathbf{g}$ & anul & regi & n/ portal/ per & -portal r & on) & \\
\hline & & Score 1:3 & $-33 \%$ & Sco & 34 & $6 \%$ & & re3:>66\% & Total & Chi-squa & \\
\hline & Group & No. $(\%)$ & & No. & & & & (\%) & & $\mathrm{X} 2$ & p-value \\
\hline $16 \mathrm{w}$ & Test(A1) & $2(20 \%)$ & & $6(6$ & & & & $0 \%)$ & 10 & 0.000 & 1.000 \\
\hline & Control(B1) & $2(20 \%)$ & & $6(6$ & & & & $0 \%)$ & 10 & & \\
\hline $18 \mathrm{w}$ & Test (A2) & $7(70 \%)$ & & 313 & & & & $\%)$ & 10 & 10.500 & $0.005^{*}$ \\
\hline & Control(B2) & $1(10 \%)$ & & $3(3$ & & & & $0 \%)$ & 10 & & \\
\hline $20 \mathrm{w}$ & Test(A3) & $8(80 \%)$ & & $2(2$ & & & & $\%)$ & 10 & 16.000 & $<0.001 * *$ \\
\hline & Control (B3) & $0(0 \%)$ & & $2(2$ & & & & $0 \%)$ & 10 & & \\
\hline
\end{tabular}

* Statistical significant difference, ** Highly statistical significant difference.

Abbreviations: PT: portal tracts, P-P: porto portal, P-C: portocaval

In addition, granulomas in test groups were fewer in number as compared to control group although this didn't mount to a statistical significant difference. This might indicate a role of (HUCB-MSCs) in hampering hepatic affection complicating intestinal schistosomiasis.
Fibrosis evaluated both by $\mathrm{H} \& \mathrm{E}$ as well as by MT was significantly reduced in test groups as compared to control groups. Extending post injection interval didn't exert a statistically significant difference within test groups (figure $5 B, 6 A$ and $6 B$ ). 


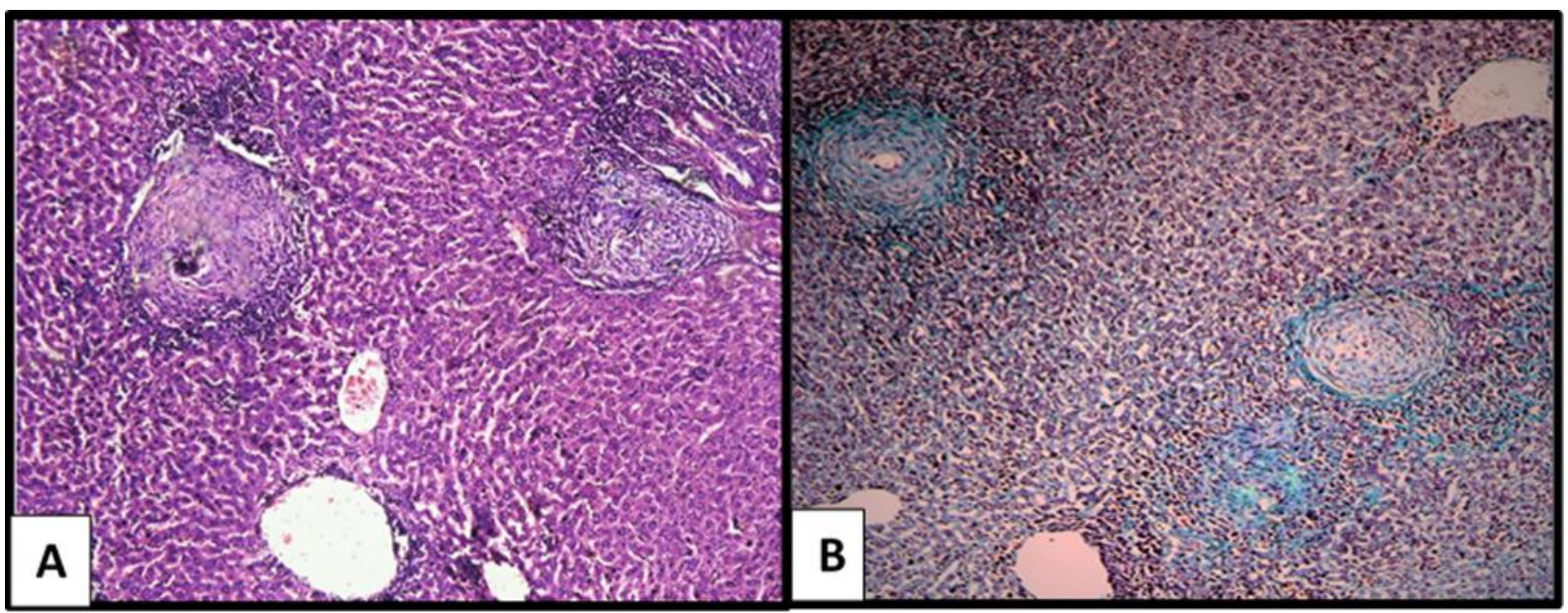

Fig. (5): Hepatic tissue section, group A3 showing only two granulomas with average size score 1, mild fibrosis and no bile ducts hyperplasia (note the white arrow). (H\&E x100) [A]- (MT X100) [B]

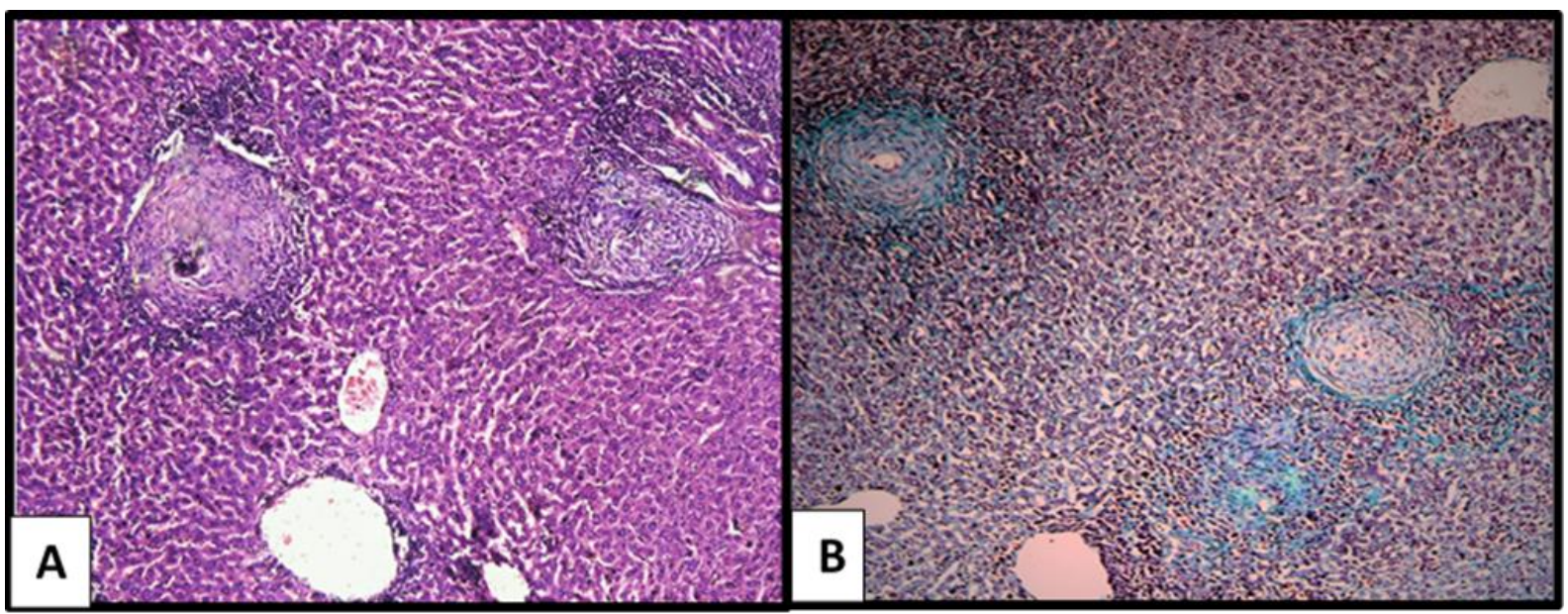

Fig. (6): Hepatic tissue sections of group B3 showing marked fibrosis with granuloma fusion and p-p bridging (H\&E x100)[A]- (MTx 100) [B]

A statistical highly significant difference was also noted among control and test groups regarding reversibility of bile duct proliferation secondary to bilharzial hepatitis (figure $\mathbf{5 A}, \mathbf{7 A}$ ). These observations delineate a potential additional effect of u-MSCs in suppressing Schistosoma eggs induced bile proliferation with a subsequent benefit of ameliorating the profibrotic sequel of such event.
SMA expression proved a statistically significant reduction in test groups as compared to control groups. Such reduction also differed significantly with extending the post injection interval within test groups. This indicated that the anti-fibrotic effect of u-MSCs involves suppression of activated hepatic stellate cells (HSCs) (figure 7 A, B, C and D). 


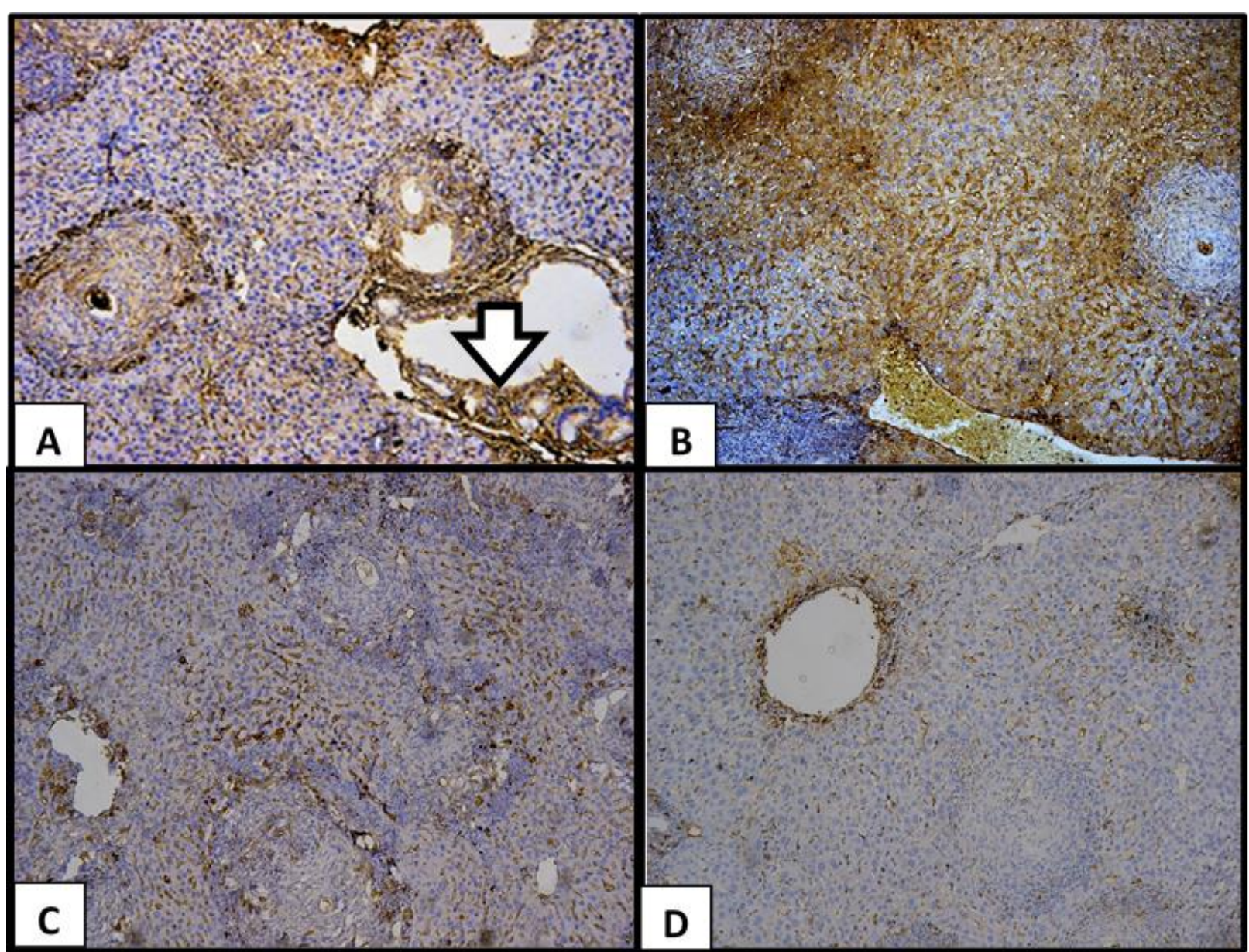

Fig. (7): Hepatic sections of different study groups showing variable smooth muscle actin immunohistochemical staining scores

Group B1 section with SMA score 2 (note associated biliary hyperplasia at the white arrow) (IHCx200) [A].

Group B3 section with SMA score 3 (IHCx200) [B]

Group A1 section with SMA score 2 (IHC x100) [C]

Group A3 section with SMA score 1 (IHC x 100) [D]

\section{Liver function tests:}

The test groups showed reduction in the serum level of liver enzyme (ALT, AST) with elevation of serum albumin level supporting the results of the histopathology and immunohistochemistry as regards the regenerative capacity of the $\mathrm{CB}$ MSCs (tab. 3).

Table (3): Biochemical tests results for group A3 and B3.

\begin{tabular}{|c|c|c|c|}
\hline & $\begin{array}{c}\text { Test group (group A3) } \\
(\text { mean } \pm \text { SD) } \\
\mathbf{N}=\mathbf{1 0}\end{array}$ & $\begin{array}{c}\text { Control group (group B3) } \\
(\text { mean } \pm \text { SD) } \\
\mathbf{N}=\mathbf{5}\end{array}$ & P value \\
\hline ALT (SGPT) & $56 \pm 4.1$ & $88 \pm 5.3 \mathrm{U} / \mathrm{I}$ & $<\mathbf{0 . 0 0 1}$ HS \\
\hline AST (SGOT) & $49.3 \pm 1.4$ & $63.8 \pm 2.1$ & $\mathbf{0 . 4 3 5}$ NS \\
\hline Albumin & $3.1 \pm 0.4$ & $2.5 \pm 0.5 \mathrm{gm} / \mathrm{dl}$ & $\mathbf{0 . 0 3 ~ S}$ \\
\hline
\end{tabular}

\section{Normal values:}

ALT: $20.69 \pm 0.66 \mathrm{U} / \mathrm{I}$.

Albumin: $5.08 \pm 1.1 \mathrm{gm} / \mathrm{dl}$.

HS: highly significant

S: significant
AST: $21.69 \pm 0.54 \mathrm{U} / \mathrm{I}$.

$\mathrm{N}$ : number of mice

NS: non significant 
As regards serum level of ALT, it showed reduction in the test groups when compared to the corresponding control group, but more reduction was obvious in $\mathrm{g}$ (A3) as compared to $\mathrm{g}$ (B3) $(\mathrm{P}<0.001)$.

The decrease of serum AST level was non-significant as contrasted with the control group $(\mathrm{P}=0.435)$.

Also, the serum level of albumin showed elevation in the test groups as contrasted with the control groups, but significant elevation was obvious in $\mathrm{g}(\mathrm{A} 3)$ in comparison to $\mathrm{g}(\mathrm{B} 3)(\mathrm{P}=0.03)$.

\section{DISCUSSION}

Biological science considers the stem cells as one of the most fascinating areas for therapeutic researches [17]. Many studies proved that MSCs can be obtained from different tissues such as bone marrow, umbilical cord, adipose tissue and amniotic fluid [18, 19]. Clinical applications of MSCs in regenerative medicine are strongly related to their intrinsic properties to modulate immune response [20].

Praziquantel still play the role of the king regarding treatment and control of schistosomiasis although many studies have question marks about the probability of tolerance and/or resistance occurrence to praziquantel [21].

So many studies investigated the stem cell-based therapies for their regenerative effect on liver diseases [22]. Different authors reported the MSCs capability to develop into hepatocytes in labs [23] and inside the human body [24]. Many studies had assumed that (HUCMSCs) are amongst the most important tools to form functional human hepatocyte-like cells [25].

This study was intended to demonstrate the effect of cord blood mesenchymal stem cells (CBMSCs) after injection into the diseased liver of mice, as a trial to create an experiential form for in vivo liver cell development from CBMSCs.

In our study, there was an improvement during the histopathological examination of the livers of the test groups in the form of a decrease in the granuloma burden in terms of size, number and the overall associated fibrosis. These effects of MSCs injection on ameliorating the schisomaisis granulomas burden are supported by authors who also proposed an adjuvant vaccine effect of MSCs [26].

MSCs induced reduction of the granuloma burden can possibly be implicated by either suppressing granuloma formation mediated by their anti-inflammatory role [27]; hence hampering the initiation of a granulomatous reaction in the first place as evidenced by our data was showing a reduction of granuloma number in test groups. However, this reduction didn't mount to a statistical significance. Additionally and alternatively, it can be attributed to the induction of involution of the pre-existing granulomas through such antiinflammatory potentials as well as possessing a regenerative impact thus allowing resolution of nearby injured hepatocytes [20]. The latter effect could be supported by the significant progressive reduction in the granuloma size we observed in test groups along with different post-injection intervals as compared to corresponding control groups.

As regards MSCs anti-fibrotic effect; our results revealed a significant decrease in hepatic collagen demonstrated by H\&E and MT stains in biopsies of test groups as compared to control groups, in addition to a concurrent statistically significant reduction in activated HSCs population reflected by SMA immunohistochemical expression. In agreement with authors proposal, we assume that this effect is attributed to enhanced fibrotic degradation rather than inhibited fibrogenesis at the granuloma area, because despite the overall reduction in collagen content yet there was a relative shift of granulomas composition towards the fibrotic rather than the cellular phase thus reflecting granulomas involution [28]. Supporting this assumption is the close association of progressive granulomatous fibrosis with its size shrinkage along with the time trend in the test groups [29].

This study is one of few to assess associated biliary hyperplasia observed with hepatic schistosomiasis in an experimental setting. The reduction of hyperplasic changes in intrahepatic biliary radicals was highly significant in test groups as compared to corresponding control groups with extended post injection intervals. Some authors reported biliary hyperplasia in hepatic schistosomiasis [30]. Other authors highlighted that biliary proliferation (ductular reaction) represents an important factor for the

Bebars et al., Afro-Egypt J Infect Endem Dis 2020;10(2):151-162

https://aeji.journals.ekb.eg/

http://mis.zu.edu.eg/ajied/home.aspx 
development and sequel of liver fibrosis. Proliferating cholangiocytes secrete pro-fibrotic factors and are thus a direct source of hepatic collagen during fibrosis [31]. Accordingly, our study offers novel observations highlighting the potential additional role of CB-MSCs in suppressing schistosomaisis induce bile proliferation with a subsequent benefit of ameliorating the pro-fibrotic sequel of such event.

We understand that our hypothetical analysis yet needs further molecular studies to investigate the involved mechanisms mediating the effect of CB-MSCs on schistosomal hepatic disease and validate our observations based postulations, thus we consider our work encouraging for such studies.

Injury of liver cells due to $S$. mansoni infection resulted in increase the serum level of hepatic transaminases [32]. From this point of view, serum SGOT, SGPT, alkaline phosphatase, and albumin gave a clue about the pathological liver damage following $S$. mansoni infection.

This research revealed that the corresponding hepatic pathology developed in the mice with $S$. mansoni-infected could be reflected by increased serum levels of ALT and AST, with reduction of serum albumin.

These results were in accordance with studies which stated that the decreased serum albumin level gave a clear image about the diminished protein synthesis from the destroyed parenchymal liver cells [33, 34].

After treatment with (HUCB-MSCs), the current work declared slight elevation of the serum albumin at the $4^{\text {th }}$ week post treatment in contrast with the control group. The transplanted CBMSCs may develop new liver cells that could produce albumin with inhibition of the transaminase release into the circulation in addition to suppression of hepatic fibrosis. There were significant improvements in the serum albumin of group (A3) in contrast with the control group (B3) at the end of the 8th weeks post treatment.

Suppression of apoptosis of the diseased liver cells or inhibition of inflammatory cells infiltration may explain the improvement of the biological profile of the liver with fibrosis [35].

So, the HUCB-MSCs showed important antifibrotic effect in liver fibrosis induced by $S$. mansoni infection with amelioration of the liver function tests. We recommend further comparative studies with the available therapies for treatment of $S$. mansoni infected livers.

\section{CONCLUSION}

The cord blood derived MSCs proved to be very beneficial and effective therapy for the treatment of diseased or damaged tissues due to their high regenerative capacity and their ability to differentiate into various cells including hepatocytes. In murine model of hepatic granuloma caused by $S$. mansoni infection, injection of poly undifferentiated MSCs resulted in decrease in the size of granuloma and fibrous tissue deposition as compared to the control group.

Funding: This work was funded by Grant Office, Faculty of Medicine, Ain Shams University.

Ethical consideration: The study was approved by the Research Ethics Committee, Faculty of Medicine, Ain Shams University. All the animal experiments were performed according to the national regulations for the Animal Ethics rules, Ain-Shams University, Cairo, Egypt.

Conflict of interest: We wish to confirm that there are no known conflicts of interest associated with this publication. We confirm that the manuscript has been read and approved by all named authors and that there are no other persons who satisfied the criteria for authorship but are not listed. We further confirm that the order of authors listed in the manuscript has been approved by all of us.

\section{REFERENCES}

1. Leonardo L, Rivera P, Saniel O, Villacorte E, Antonnette, M. National baseline prevalence survey of schistosomiasis in the Philippines using stratified two-step systematic cluster sampling design. J Trop Med 2012; doi: 10.1155/2012/936128.

2. Kadry SM, Mohamed AM, Farrag EM, Fayed DP. Influence of some micronutrients and Citharexylum quadrangular extract against liver fibrosis in Schistosoma mansoni infected mice. Afr. J. Pharmacol. 2013; 7 (38): 2628-2638.

3. WHO 2010

4. Gryseels B, Polman K, Clerinx J, Kestens L. Human schistosomiasis. Lancet 2006; 368: 11061118 . 
5. El Ridi R, Tallima H, Dalton JP, Donnelly S. Induction of protective immune responses against schistosomiasis using functionally active cysteine peptidases. Front. Genet. 2014; 8 (5): 119-132

6. Svendsen $\mathrm{CN}$. Back to the future: How human induced pluripotent stem cells will transform regenerative medicine. Hum Mol Genet 2013; 3: 22-38.

7. Gamez-Escalona JA. IPS an ethical paradigm for biomedical research. Caud Bioet 2013; 24: 419442.

8. Pittenger MF, Mackay AM, Beck SC, Jaiswal RK, Douglas R, Mosca, JD, et al. Multilineage potential of adult human mesenchymal stem cells. Science 1999; 284 : 143-152.

9. Takahashi $\mathrm{K}$ and Yamanaka S. Induced pluripotent stem cell in medicine and biology. Development 2013; 140: 2457-2461.

10. Hammam OA, Elkhafif N, Attia YM, Mansour MT, Elmazar MM, Abdelsalam RM, et al. Wharton's jelly-derived mesenchymal stem cells combined with praziquantel as a potential therapy for Schistosoma mansoni-induced liver fibrosis. Scientific Reports 2016; 6: 210-225.

11. Broxmeyer HE, Cooper S, Hass DM, Hathaway JK, Stehman FB. Experimental basis of cord blood transplantation. Bone Marrow Transplant 2009; 44: 627-633.

12. Mc Farlin K, Gao X, Liu YB, Dulchavsky DS, Kwon D, Arbab AS, et al. Bone marrow-derived mesenchymal stromal cells accelerate wound healing in rat. Wound Repair and Regen 2006; 14 : 471-478.

13. Maria AO, Donadel S, Wendel GH, Guzman JA, Guerreiro E, Giordano OS. Gastric anti-ulcer activity of several alpha,beta-unsaturated carbonyl compounds in rats. Biol Pharm Bull. 2000; 23 (5): 555-7.

14. Zakaria S, Youssef M, Moussa M, Maha AM, ElAhwany E, El-Raziky M, et al. Value of $\alpha$-smooth muscle actin and glial fibrillary acidic protein in predicting early hepatic fibrosis in chronic hepatitis C virus infection. Arch. Med. Sci 2010; 6 (3): 356-365.

15. Dumas BT, Watson WR. Albumin standard and the measurement of serum albumin with bromcresol green. Clin Chim Acta 1997; 258: 2130.

16. Reitman SA. Colorimertic method for the determniation of serum glutamic oxalacetic and glutamic pyruvic transaminases. Am J Clin Pathol 1957; 28: 56-63.

17. Xu L, Liu Y, Sun Y, Wang B, Xiong Y, Lin Wvet, al. Tissue source determines the differentiation potentials of mesenchymal stem cells: A comparative study of human mesenchymal stem cells from bone marrow and adipose tissue. Stem Cell Research and Therapy 2017; 8: 275-299.
18. Zhang D, Liu X, Peng J, He D, Lin T, Zhu J. Potential spermatogenesis recovery with bone marrow mesenchymal stem cells in an azoospermic rat model. Int J Mol Sci 2014; 15: 13151-13165.

19. Li D, Chai J, Shen C, Han Y, Sun T. Human umbilical cord-derived mesenchymal stem cells differentiate into epidermal-like cells using a novel co-culture technique. Cytotechnology 2014; 66: 699-708.

20. Patel MD, Shah J, Anand S, Srivastava SA. Therapeutic potential of mesenchymal stem cells in regenerative medicine. Stem Cell Research and Therapy 2013; 5: 115-130.

21. Wang W, Wang L, Liang YS. Susceptibility or resistance of praziquantel in human schistosomiasis: A review. Parasitol Res 2012; 111: 1871-1877.

22. Puglisi MA, Saulnier N, Piscaglia AC, Tondi P, Agnes S, Gasbarrini A. Adipose tissue-derived mesenchymal stem cells and hepatic differentiation: old concepts and future perspectives. Eur Rev Med Pharmacol Sci 2011; 15 (4): 355-364.

23. Feng Z, Li C, Jiao S, Hu B, Zhao L. In- vitro differentiation of rat bone marrow mesenchymal stem cells into hepatocytes. Hepatogastroenterol. 2011; 58 (112): 2081-2086.

24. Hwang S, Hong HN, Kim HS, Park SR, Won YJ, Choi, ST et al. Hepatogenic differentiation of mesenchymal stem cells in a rat model of thioacetamide-induced liver cirrhosis. Cell Biol. Int. 2012; 36 (3): 279-288.

25. Amati E, Sella S, Perbellini O, Alghisi A, Bernardi M, Chieregato K, et al. Generation of mesenchymal stromal cells from cord blood: Evaluation of in-vitro quality parameters prior to clinical use. Stem Cell Res Ther 2017; 8: 14-30.

26. Etewa SE, Abd Allah HS, Maha SR, Sally M, Amal S, Mahmoud A, et al. The effect of stem cells as an adjuvant on the immunogenicity of apotential anti schistosomal vaccine in mice. $J$. Egyp. Soc. Parasitol. 2016; 7: 693 - 716.

27. Eom WY, Shim YK, Baik KS. Mesenchymal stem cell therapy for liver fibrosis. Korean $J$ Intern Med 2015, 30: 580-589.

28. Abdel Aziz MT, Atta HM, Roshdy NK, Rashed LA, Sabry D, Hassouna AA, et al. Amelioration of murine Schistosoma mansoni induced liver fibrosis by mesenchymal stem cells. J. Stem Cells Regen. Med. 2012; 8 (1): 28-34.

29. Ghanem LY, Dahmen U, Dirsch O, Nosseir MM, Mahmoud SS. Does granulocyte-colony stimulating factor administration induce damage or repair response in schistosomiasis? World $J$. Hepatol 2010; 2: 434-441. 
30. Hurst MH, Shi, Y.E.; Lindberg, R. Pathology and course of natural Schistosoma japonicum infection in pigs: Results of a field study in Hubei province, China. Ann. Trop. Med. Parasitol. 2000; 94: 461477.

31. Glaser S, Gaudio E, Miller T, Alvaro D, Alpini G. Cholangiocyte proliferation and liver fibrosis. Expert Rev Mol Med 2009; 11: 7.

32. Hanna LS, Medhat AM, Abdel-Menem HA. Biochemical changes after subchronic and chronic interaction of Schistosoma mansoni infection in Swiss albino mice with two specific compounds. J. Egypt. Soc. Parasitol. 2003; 33: 245-260.
33. Abdel-Rahim IM, Kaiser C, Homeida MA, Elsheikh M, Schmidt E, Ehrich JH, et al. Enzyme activities and protein concentrations in serum of patients with hepatosplenic schistosomiasis. Trop. Med. Parasitol. 1990; 41 : 262-264.

34. Mahmoud MR, El-Abhar HS, Saleh S. The effect of Nigella sativa oil against the liver damage induced by Schistosoma mansoni infection in mice. J. Ethnopharmacol 2002; 79: 1-11.

35. Shi M, Zhang Z, Xu R, Lin H, Fu J, Zou Z, et al. Human mesenchymal stem cell transfusion is safe and improves liver function in acute-on-chronic liver failure patients. Stem Cells Transl Med 2012; 1: $725-731$ 